\title{
Green Filtration of Total Solids from Various Water Sources Using Coconut Coir and Loofah
}

\author{
Adedeji A. Adelodun \\ Department of Marine Science \& Technology, School of Earth \& Mineral Sciences, The Federal University of Technology, Akure, \\ Nigeria \\ E-mail: aaadelodun@futa.edu.ng
}

Received: 30 March 2021; Revised: 20 May 2021; Accepted: 29 June 2021

\begin{abstract}
In this study, environmentally benign and readily available organic waste materials (coconut coir and loofah) were used as biofilters to remove total solids (TS) in water samples from various sources in Araromi Coastal Region of Ilaje Local Government, Nigeria. The TS levels observed in the river, pond, well, borehole, and seawater samples were $4,000,1,610,3,980,2,600$, and $34,800 \mathrm{mg} / \mathrm{L}$, respectively. Generally, the organic filters reduced the TS in the water samples. Also, the sorption efficiency increased with the filter mass-to-water volume ratio. The overall performance of coconut coir was better than loofah, probably because the former has a more closely packed fibrous mesh. The optimum sorption efficiency of $60 \mathrm{~g}$ of the coconut coir filter for river, pond, well, borehole, and sea water was $50 \%, 78 \%, 80 \%$, $92.3 \%$, and $48.8 \%$, while those for loofah were $42.5 \%, 56.3 \%, 70 \%, 84.6 \%$, and $40.2 \%$, respectively. This work showed that pretreated coconut coir is an efficient green filter for TS in water sources, especially boreholes, wells, and ponds.
\end{abstract}

Keywords: filtration, organic filters, Cocos nucifera L, Luffa aegyptiaca, total solids

\section{Introduction}

According to the World Health Organization (WHO), more than 33\% of the human population have no access to safe drinking water [1]. WHO reported that approximately 1.6 million people, predominantly children, die every year from waterborne diseases [2]. Governments, corporate bodies, non-governmental organizations, and researchers are concerned that potable water scarcity remains a major global problem [3]. Moreover, global water demand could rise by 20 to $30 \%$ by 2050 [4], thereby requiring efficient water purification technologies. Therefore, it is crucial to identify an alternative to purify unpotable water using a low-cost, readily available, and low-tech method.

Boiling, liming, ozonolysis, chlorination, iodine or bromine treatment, UV-disinfection, ozonation, reverse osmosis, phytoremediation, bioremediation, adsorption, absorption, and filtration are among the techniques often used for water treatment [5]. Most of these techniques have shown inherent deficiencies, such as high energy demand, tediousness, high financial requirements, environmental hazard via secondary pollution and others. However, of these methods, filtration is the most conventional, convenient, and benign technique for separating solids from liquids [6,7].

Luffa aegyptiaca (luffa or loofah sponge) has been reportedly used to ameliorate ammonium-laden wastewater [8]. In this study, the efficiency $(79.4 \pm 8.82 \%)$ and durability of the green filter were found to be excellent. Earlier, loofah was used to control various surface water pollutants, such as alkalinity, chloride, ammonium, bacteria, and suspended

Copyright (C2021 Adedeji A. Adelodun

DOI: https://doi.org/10.37256/epr.112021847

This is an open-access article distributed under a CC BY license

(Creative Commons Attribution 4.0 International License)

https://creativecommons.org/licenses/by/4.0/ 
solids [9]. Therein, the authors reported $48.33 \%$ removal efficiency for total suspended solids (TSS). Meanwhile, coconut husk fiber (coconut coir), among other water purifiers (zeolite, charcoal, and membrane), has been tested for its rainwater purification efficiency [10]. The study found that the green filter is comparatively efficient, but it still requires some pretreatment and modification. In the same year, a group of scientists studied the use of loofah and coconut fiber to improve the biochemical oxygen demand, dissolved oxygen, turbidity, and color of the wastewater [11]. As a result, both organic filters managed to improve the water quality.

So far, no comparative study has been reported between pristine coconut coir and loofah filters on various water sources, especially seawater. Coconut trees flourish in high salinity regions, where potable water is often scarce. Therefore, in this study, locally sourced and readily available organic (green) filters derived from coconut coir and loofah were experimented on various water sources originating from Araromi Coastal Region, Ilaje Local Government Area of Ondo State, Nigeria.

\section{Materials and methods}

\subsection{Sampling area and method}

Araromi (longitude $4^{\circ} 49^{\prime} 59^{\prime \prime} \mathrm{E}$ and latitude $6^{\circ} 22^{\prime} 43^{\prime \prime} \mathrm{N}$ ) is a rural coastal community in Ilaje Local Government Area, Ondo State, Nigeria. Samples were obtained from various water sources in Araromi, including the sea, estuary, river, well, pond, and borehole. The collected samples were stored in plastic bottles before use. Coconut coir was collected from a mature coconut tree (Cocos nucifera L) in Araromi, while the pristine and sundried loofah (Luffa aegyptiaca) used was obtained from a local market. 20,40, and $60 \mathrm{~g}$ of each filter were precleaned in $1 \mathrm{M} \mathrm{HNO}_{3}$ solution before copiously rinsed with distilled water. Finally, they were air-dried before being used.

\subsection{Experimental setup}

Initially, $50 \mathrm{~mL}$ of the water sample placed in a precleaned and dried $100 \mathrm{~mL}$ beaker was evaporated for $30 \mathrm{~min}$ in an electric oven set at $105^{\circ} \mathrm{C}$. Then, the beaker was transferred into a desiccator to cool to room temperature. Finally, it was reweighed. The total solids (TS) is calculated according to the following equation:

$$
T S=\frac{(A-B) \times 1000}{\text { amount of water }(\mathrm{mL}) \times 1000}
$$

where A is the mass of the empty beaker and B is the mass of the beaker with dried solid. TS represents the sum of TSS and total dissolved solids (TDS) in water. TS is an indicator for characterizing water chemical properties, such as clarity, photosynthetic activities, and organisms' productivity. The initial TS concentration ratio of 2.5:1:2.5:1.6:21.6 in the river, pond, well, borehole, and sea water was recorded.

For the green filter, 20,40, and $60 \mathrm{~g}$ of the organic filter were placed in a precleaned and dried funnel that was positioned on a $100 \mathrm{~mL}$ beaker. $50 \mathrm{~mL}$ aliquot was gently poured through the filter. The filtration process was assumed to be complete when no more drops were visible, which took approximately 1 to $4 \mathrm{~min}$. The filtrate was then collected and analyzed for TS. The residual TS is determined by the difference in TS values with and without the organic filter.

Further, the removal or sorption efficiency, which is the percentage of TS uptake by the sorbent, also known as percentage removal, is determined by using Equation 2 [12],

$$
\text { Removal efficiency }=\frac{C_{0}-C_{1}}{C_{0}} \times 100 \%
$$

where $\mathrm{C}_{0}$ and $\mathrm{C}_{1}$ imply the TS concentrations before and after adsorption, respectively. 


\section{Results and discussion}

Figure 1 depicts the TS residual concentrations observed when the biofilters were used on the seawater samples, while Figure 2 compares the biofilters' TS removal efficiency of the other water sources.

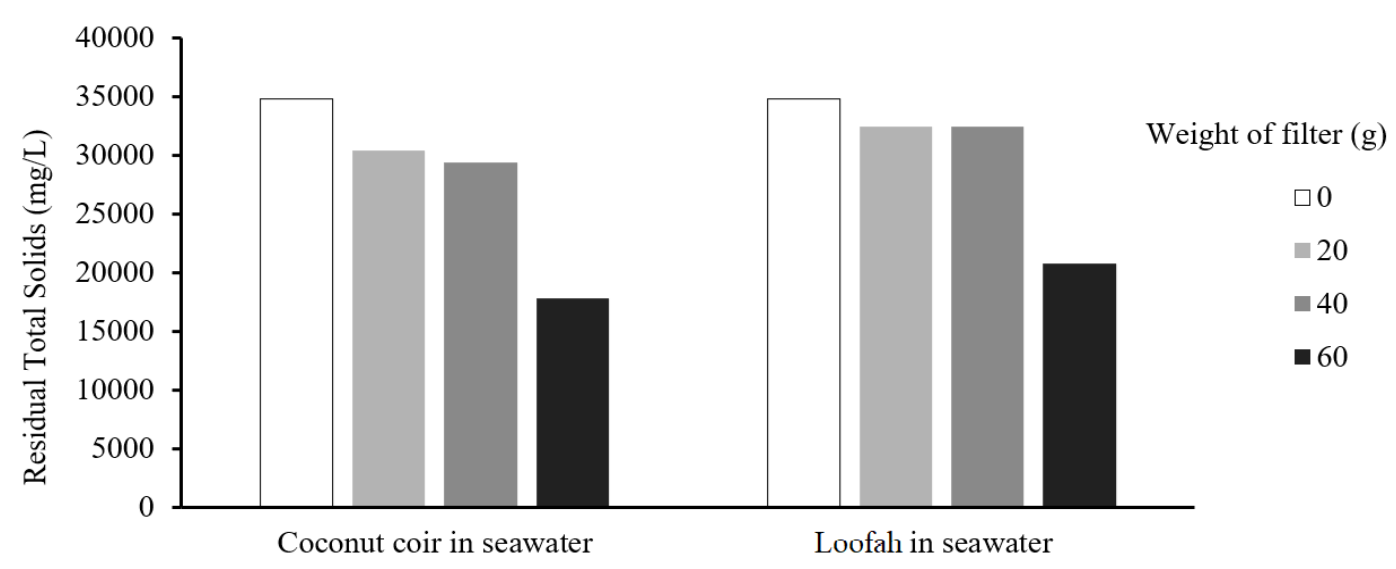

Figure 1. Residual concentration comparison of total solids in seawater for 20, 40, and $60 \mathrm{~g}$ of coconut coir and loofah filters
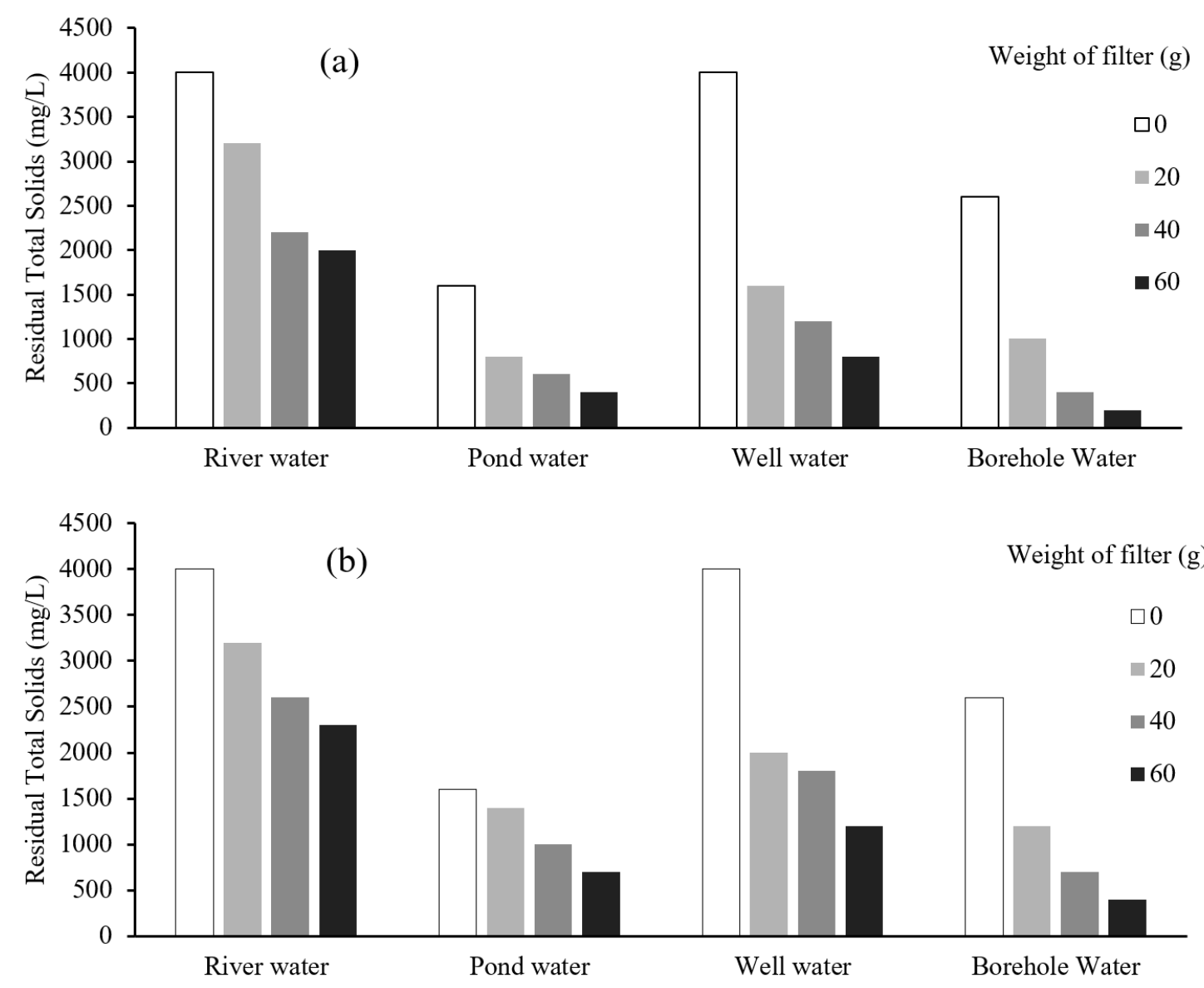

Figure 2. Residual concentration comparison of total solids in river, pond, well, and borehole water samples for different weights of (a) coconut coir and (b) loofah filters 
The results showed that the TS concentrations in the water samples exceeded the WHO permissible limit of $500 \mathrm{mg} / \mathrm{L}[13,14]$. Such high values could be attributed to the close proximity of water sources to the sea, which is frequently associated with high levels of suspended solids (SS) and TDS [15]. The results also showed that the TS concentrations decreased with increasing filter weight. Here, the TS levels for the pond and borehole water fell within the WHO permissible limit after the application of green filtration. Thus, it is proven that using the green filters on the pond and borehole water from the Araromi coastal region could result in water that is safe for human consumption.
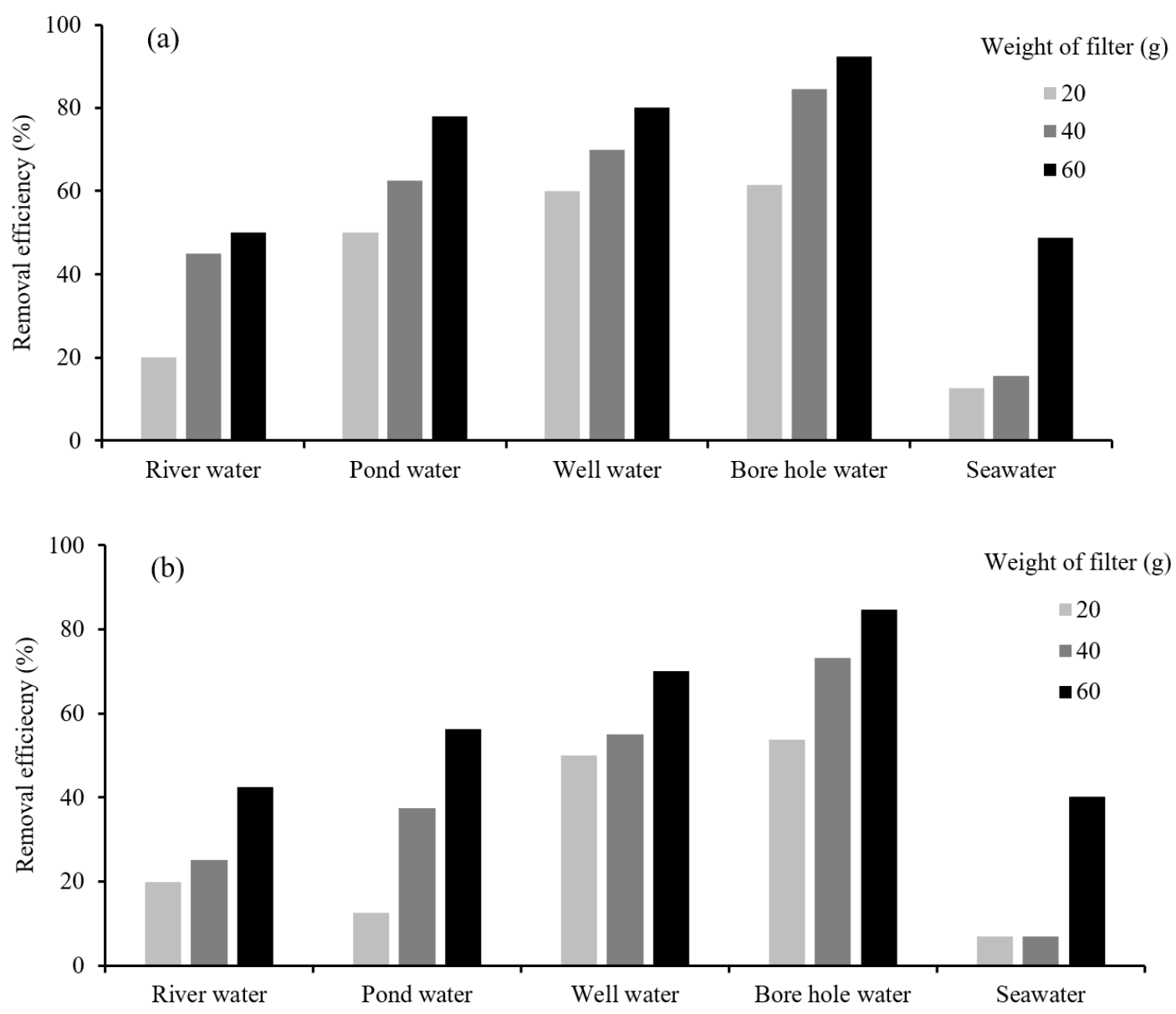

Figure 3. Removal efficiency comparison of total solids in river, pond, well, and borehole water samples for different weights of (a) coconut coir and (b) loofah filters

Figure 3 illustrates the results of the estimated removal efficiency. From this estimation, it is confirmed that coconut coir is more efficient than loofah. Also, despite their low concentrations of solids, the borehole water and seawater had the highest and lowest susceptibility to solid removal. As expected, the sorption efficiency improved with the filter weight, although not proportionally. For the pond and well water samples, the sorption efficiency was proportional to the weight of the coconut coir filter. However, in some cases, increasing the filter weight from 20 to $40 \mathrm{~g}$ was more effective when compared to the 40 to $60 \mathrm{~g}$ increment, particularly for the river and borehole water samples filtered using coconut coir, and pond and borehole water samples filtered using loofah. Meanwhile, it was the reverse for the sea water samples filtered with coconut coir, and the river and seawater samples filtered using loofah. These haphazardness or anomaly could be attributed to the accidental release of fines from the filters due to the absence of binders that could adhere the filter fibers together, or the lack of calcination of the green filters during sample preparation. 
The optimum performance reported in the present work was compared with previous studies where different techniques and materials were used to remove solids from various water samples (Table 1).

Table 1. Optimum removal efficiency comparison achieved under different total solids removal methods

\begin{tabular}{|c|c|c|c|c|}
\hline No. & Material used & Method used & Optimum removal efficiency & Ref. \\
\hline 1 & Nonwoven geotextile & Upward filtration system & $88.5 \%$ & [16] \\
\hline 2 & Fe electrodes & Electrocoagulation & $99 \%$ & [17] \\
\hline 3 & $\begin{array}{l}\text { Pumice and Sand-gravel } \\
\text { mixture }\end{array}$ & Media filter systems & $90.5 \%$ & [18] \\
\hline 4 & Okra powder & Coagulation-flocculation & $73 \%$ & [19] \\
\hline 5 & $\begin{array}{l}\text { Chemical additives } \\
\mathrm{Al}_{2}\left(\mathrm{SO}_{4}\right)_{3}\end{array}$ & Electroflocculation & $98 \%$ & [20] \\
\hline 6 & Waste bivalve shells & Simple filtration & $81 \%$ & [21] \\
\hline 7 & Natural Esker & Sand filtration & $40 \%$ & [22] \\
\hline 8 & Coconut coir & Simple filtration with virgin material & $\begin{array}{l}48.8-92 \% \text { (depending on } \\
\text { the water source) }\end{array}$ & Current study \\
\hline
\end{tabular}

By comparison, only electrocoagulation [17] and electroflocculation [20] techniques performed better than the current study's filtration method using coconut coir. Meanwhile, the sand filtration method requires an upgrade to provide better performance even though the optimum removal efficiency is the lowest (see Table 1) [22]. For this reason, the excellent performance of the coconut coir filter has proven to be a viable option for a simpler water purification method.

\section{Conclusion}

The present study identified that both coconut coir and loofah biofilters were able to remove TS from the river, pond, well, borehole, and seawater samples. Although the biofilters' sorption efficiency increased with the weight of both coconut coir and loofah filters, the coconut coir showed better and consistent performance across the water samples. From the initial TS concentration ratio of 2.5:1:2.5:1.6:21.6 in the river, pond, well, borehole, and sea water, the coconut coir filter was able to achieve the optimum sorption efficiency of $50 \%, 78 \%, 80 \%, 92.3 \%$, and $42.8 \%$, while those for loofah were $42.5 \%, 56.3 \%, 70 \%, 84.6 \%$, and $40.2 \%$, respectively. As a result, coconut coir is an effective TS biofilter, particularly for water samples from boreholes, wells, and ponds.

In the future, more research involving the feasibility of enhancing the filters' performance via surface charging should be done. It is also recommended to explore the chemical characterization of the surface chemistry and pore-size distribution for the possibility of chemisorption and physisorption studies of the material used.

\section{References}

[1] World Health Organization (WHO). 1 in 3 people globally do not have access to safe drinking water. Geneva: WHO; 2019. Available from: https://www.who.int/news/item/18-06-2019-1-in-3-people-globally-do-not-haveaccess-to-safe-drinking-water-unicef-who.

[2] Osiemo MM, Ogendi GM, M'Erimba C. Microbial quality of drinking water and prevalence of water-related diseases in Marigat Urban Centre Kenya. Environmental Health Insights. 2019; 13: 1-7.

[3] Cosgrove WJ, Loucks DP. Water management: current and future challenges and research directions. Water Resources Research. 2015; 51(6): 4823-4839.

[4] Burek P, Satoh Y, Fischer G, Kahil MT, Scherzer A, Tramberend S, Nava LF, Wada Y, Eisner S, Flörke M, Hanasaki N, Magnuszewski P, Cosgrove B, Wiberg D. Water Futures and Solution - Fast Track Initiative (Final Report). Austria: International Institute for Applied Systems Analysis (IIASA) Working Paper; 2016.

[5] Collivignarelli MC, Abba A, Benigna I, Sorlini S, Torretta V. Overview of the main disinfection processes for 
wastewater and drinking water treatment plants. Sustainability. 2018; 10(1): 86.

[6] Monika N, Nikhil V, Ayushi M, Sakshi G. Organic filters: an upcoming water treatment methodology. International Journal of Engineering and Manufacturing Science. 2017; 7(1): 30-34.

[7] Ullah A, Shahzada K, Khan SW, Strarov V. Purification of produced water using oscillatory membrane filtration. Desalination. 2020; 491: 114428.

[8] Zhang J, Yang J, Tian Q, Liang X, Zhu Y, Sand W, Li F, Ma C, Liu C, Yang B. Durability and performance of loofah sponge as carrier for wastewater treatment with high ammonium. Water Environmental Research. 2019; 91(7): 581-587.

[9] Adie DB, Igoro SB, Daouda N, Eladere E. Determination of the filter potential of luffa sponge (luffa aegyptica) in water quality analysis. American International Journal of Contemporary Research. 2013; 3(3): 117-123.

[10] Emm L. Water filter production using coconut husk fiber, zeolite, charcoal, and membrane for rainwater harvesting. Malaysia: Politeknik Sultan Idris Shah; 2018. Available from: https://www.researchgate.net/publication/326682453.

[11] Selamat NA, Mardi NH, Zaini NA. Preliminary study on the application of loofah fiber and coconut fiber in water filtration. AIP Conference Proceedings. 2018; 2030(1): 020262.

[12] Al-Senani GM, Al-Fawzan FF. Study on Adsorption of $\mathrm{Cu}$ and Ba from Aqueous Solutions Using Nanoparticles of Origanum (OR) and Lavandula (LV). Bioinorganic Chemistry and Applications. 2018; 1-8.

[13] Kumar M, Puri A. A review of permissible limits of drinking water. Indian Journal of Occupational and Environmental Medicine. 2012; 16(1): 40-44.

[14] Oluyemi EA, Adekunle AS, Adenuga AA, Makinde WO. Physico-chemical properties and heavy metal content of water sources in Ife North Local Government Area of Osun State, Nigeria. African Journal of Environmental Science and Technology. 2010; 4(10): 691-697.

[15] Elemile OO, Raphael DO, Omole DO, Oloruntoba EO, Ajayi EO, Ohwavborua NA. Assessment of the impact of abattoir effluent on the quality of groundwater in a residential area of Omu-Aran, Nigeria. Environmental Science Europe. 2019; 31: 16.

[16] Inoue T, Fukue M, Mulligan CN, Uehara K. In situ removal of contaminated suspended solids from a pond by filtration. Ecological Engineering. 2009; 35: 1249-1254.

[17] Sadeddin K, Naser A, Firas A. Removal of turbidity and suspended solids by electro-coagulation to improve feed water quality of reverse osmosis plant. Desalination. 2010; 268: 204-207.

[18] Kuslu Y, Sahin U. A comparison study on the removal of suspended solids from irrigation water with pumice and sand-gravel media filters in the laboratory scale. Desalination and Water Treatment. 2013; 51(10-12): 2047-2054.

[19] de Jesus E, Cruz PV, Pacífico JA, Silva AS. Removal of turbidity, suspended solids and ions of Fe from aqueous solution using Okra powder by coagulation-flocculation process. American Journal of Water Resources. 2013; 1(3): $20-24$.

[20] Moayedi H, Kazemian, S, Vakili AH, Ghareh S, Nazir R. Coagulation of the suspended organic colloids using the electroflocculation technique. Journal of Dispersion Science and Technology. 2013; 25: 273-282.

[21] Morata AS, Caligan JT, Capio TB, Regatalio KD. Water quality and removal efficiency of suspended solids, copper, lead, and oil/grease in Malihao River, Negros Occidental, Philippines using bivalve shells. KIMIKA. 2019; 30(2): 49-60.

[22] Lindroos AJ, Lindholm-Lehto P, Pulkkinen J, Kiuru T, Vielma J. The effect of filtration with natural Esker sand on the removal of organic carbon and suspended solids from the effluent of experimental recirculating aquaculture systems. Water Air Soil Pollution. 2020; 231: 1-10. 